\title{
A Study on the Prevalence of Subclinical Mastitis in Lactating Cows and Associated Risk Factors in Wolmara District, Oromia Regional State, Ethiopia
}

\author{
Debela Abdeta $^{1 *}$ and Birhanu Gemechisa ${ }^{2}$ \\ ${ }^{1}$ School of Veterinary Medicine, Wollega University of Gondar, Ethiopia \\ ${ }^{2}$ Holeta District Livestock and Fishery Office, Ethiopia \\ *Corresponding author: Debela Abdeta, School of Veterinary Medicine, Wollega University of Gondar, P.0. Box 395, Nekemte, \\ Ethiopia
}

\section{ARTICLE INFO}

Received: May 27, 2020

Published: 幽 June 12, 2020

Citation: Debela Abdeta, Birhanu Gemechisa. A Study on the Prevalence of Subclinical Mastitis in Lactating Cows and Associated Risk Factors in Wolmara District, Oromia Regional State, Ethiopia. Biomed J Sci \& Tech Res 28(2)-2020. BJSTR. MS.ID.004621.

Keywords: Lactating Dairy Cows; Prevalence; Risk Factors; Sub Clinical Mastitis; Wolmera District

\section{ABSTRACT}

A cross-sectional study was conducted to estimate the prevalence and associated risk factors of mastitis in dairy cows. The present study was carried out to investigate prevalence of subclinical mastitis (SCM) in milking cows and risk factors associated with sub-clinical mastitis. A total of 384 lactating cows were randomly selected to identify the SCM from 12 PAS of Wolmera Woreda and cow information was collected from the farmers' thought interview. Milk samples were collected aseptically from California mastitis test (CMT) positive cows. Result showed that 172 lactating cows $(44.8 \%)$ and $358(93.2 \%)$ quarters were positive to CMT. The prevalence of SCM was $(\mathrm{p}<0.05)$ significantly high in European crossbreds $(56.5 \%)$ compared to local breed (36.3\%). The highest prevalence found in the age group (4-7) years and the highest prevalence in parity more than 4 year was $37.2 \%$. The prevalence was significantly $(\mathrm{p}<0.05)$ higher in cows with earlier lactation $(41.3 \%)$. This study indicated a higher prevalence of mastitis linked with several risk factors. Thus, early diagnosis and regular screening of cows for subclinical mastitis together with proper therapeutic management of clinical cases are of paramount importance. Moreover, control and prevention strategies should be designed and implemented with great emphasis given to risk factors to reduce bovine mastitis and its impact on milk production and food security.

\section{Introduction}

In Ethiopia, livestock represents a major national resource and form an integral part of the agricultural production system. The country has the largest livestock population of any African country with estimated 43.1 million heads of cattle and cows representing the largest proportion of indigenous cattle of the country [1]. Milk produced from these animals provides an important dietary source for the majority of rural as well as a considerable number of the urban and peri-urban population. However, milk production often does not satisfy the country's requirements due to a multitude of factors, out of which disease of the mammary glands known as mastitis is among the various factors contributing to reduced milk production [2]. Mastitis is defined as an inflammation of the parenchyma of mammary gland, which can reduce milk yield and alter milk composition [3]. There are two main classes of mastitis.
The first is clinical mastitis, which manifests signs observed from the animal or the milk. The other is subclinical mastitis, which produces no visible signs from the udder except when using diagnostic tools. Since the quality and quantity of the milk is influenced by mastitis, it is considered to be one of the most important causes of economic losses in the dairy industry worldwide. Mammary gland infections cost the US dairy industry approximately 2 billion dollars annually and have a similar impact in Europe [4].

Somatic cells are part of the natural defence mechanism and include lymphocytes, macrophages, polymorphonuclear cells and some epithelial cells [5]. Somatic cell count (SCC) can be measured quantitatively by California mastitis test (CMT). It is a simple, easy and low-cost screening test for subclinical mastitis at dairy farms. Validity of CMT in diagnosis of infected quarters was established in 
various milking stages [6,7]. Mastitis is the most frequent diseases of dairy cow and reduces quality of milk. About 140 to 200 USD / Cow/Year ease next to reproductive disorders and one of the major causes for economy failure in Ethiopia [2]. In Ethiopia mastitis prevalence rate was $85.6 \%$ and $81.2 \%$ using CMT and somatic cell count (SCC), respectively [8]. An over all of 30.2 and 5.5\% for subclinical and clinical mastitis respectively [9]. Most of the previous studies in Ethiopia were concentrated on the investigation of the prevalence and few risk factors for mastitis at cow level and no or little effort has been made to assess the prevalence, management and hygienic practices at herd/farm-level. A focused study on contagious mastitis with emphasis on subclinical type is lacking. Besides, teat morphology, which is inherited anatomical feature of the cow that may affect mastitis occurrence and could serve as a marker trait for selection to reduce mastitis in dairy cattle, is less investigated. It is therefore important to assess the effect of the variable on clinical and sub-clinical mastitis under Ethiopian condition and recommend preventive measures to reduce loss attributed to the disease. Moreover, given the huge economic relevance due to lack of clinical visibility and subsequent effects, investigation of sub-clinical mastitis at herd-level is of paramount importance for designing feasible prevention and control strategy $[10,11]$.

Despite high cattle population and milk production potential of the study area, sub clinical mastitis is insufficiently investigated and information relating to its magnitude, distribution and risk factors is scant. Thus, the objectives of the study will be:

a. To evaluate the prevalence of subclinical mastitis in apparently healthy dairy cows in Wolmera district.

b. To evaluate associated risk factors affecting on subclinical mastitis

\section{Materials and Methods}

\section{Study Area}

The study was conducted in and around Holeta town located $45 \mathrm{~km}$ away from Addis Ababa in the south west direction, $9^{\circ} 3^{\prime} \mathrm{N}$ and $38^{\circ} 30^{\prime} \mathrm{E}$, at an altitude of $2,400 \mathrm{~m}$ above sea level in central highlands. The area is characterized by mild subtropical weather with minimum and maximum temperature ranging from 2 to $9{ }^{\circ} \mathrm{C}$ and 20 to $27{ }^{\circ} \mathrm{C}$, respectively. The area receives annual rainfall of $1060 \mathrm{~mm}$ [9].

\section{Study Population}

A total of 384 dairy cows were examined in different kebeles of Wolmera district such us, (G/kuyu, G/qerans, B/harbu, W/ harbu, T/harbu, Shola, Sadamo, Damotu, W/choke, Walmara, Q/ odo, B/qorodo, B/2ffaa, Bu/harbu, B/1ffaa). The dairy cows were distributed according to breed (local cows, Holstein Friesian breed, Jersey and Holstein crossed with Borena), age (cows aged less than 6 years young and cow aged greater than or equal to 6 years old). all dairy cows with no clinical symptoms were examined. All animals were subjected to clinical and physical examinations, with special interest towards the udder and teats. At the time of each examination, the breed of the cow, age of the cow, health status of the mammary glands and the respective kebele were recorded.

\section{Study Design}

A cross sectional study was conducted from July 2017 to December 2017. Dairy animals were selected from different kebeles of the district and examined by California mastitis test for the presence or absence of sub clinical mastitis at Wolmera district veterinary clinic.

\section{Sample Size and Sampling Method}

Simple random sampling technique was followed to select the study animal, and the desired sample size had been calculated according to the formula given in [12]. Since there is no previous report on this issue $50 \%$ expected prevalence is used.

$$
n=1.962 P \exp (1-P \exp ) / d^{2}
$$

Accordingly, a total of 384 dairy cows were examined in different kebeles of Wolmera district.

\section{Sample Collection and CMT Test}

The udders and especially teats were cleaned and dried before sample collection. Each teat end had been scrubbed with cotton moistened with $70 \%$ ethyl alcohol. A squirt of milk, about $2 \mathrm{ml}$ from each quarter was placed in each of four shallow cups in CMT paddle. And then an equal amount of the CMT reagent $(4 \% \mathrm{NaOH}$ in distilled water and $1 \%$ bromothymol blue) wasadded to each cup. A gentle circular motion was applied to the mixtures in a horizontal plane for 15 seconds. Based on the thickness of the gel formed by CMT reagent-milk mixture, test results were scored as 0 (negative/ trace), +1 (weak positive), +2 (distinct positive), and +3 (strong positive). Positive CMT-cows were defined as having at least one CMT-positive quarter.The total number of blind teats as well as those with clinical infection was subtracted from the total number of teats and the difference was used to calculate the prevalence of subclinical mastitis.

\section{Physical Examination of Mastitis}

Udder attachment, parity number, any physical abnormalities such as swelling of the udder, presence of lesions, anatomical malformations and tick infestation were recorded. The milk was examined for its colour, odour, consistency and other abnormalities.

\section{Data Analysis}

The data was compiled and analysed with Statistical Package for Social Sciences (SPSS statistical package version 17). Prevalence estimation of positive cows was determined using standard formulae (that is, the number of positive animals/samples divided by the total number of animals/samples examined). Descriptive 
statistics such as percentages and frequency distributions were used to describe/present the nature and the characteristics of the data

\section{Results}

Out of 384 examined172 cow have subclinical mastitis with prevalence of 44.8 .

\section{Severity of Subclinical Mastitis on CMT Test}

Based on the CMT result $86(50 \%)$ cows had weak infection, $76(44.2 \%)$ had distinct positive and $10(5.8 \%)$ cows had strong positive (Tables 1\&2).

Table 1: Degree of severity of subclinical mastitis.

\begin{tabular}{|c|c|c|}
\hline CMT Result & Number Positive & Percentage \\
\hline Weak positive (1) & 86 & 50.0 \\
\hline Distinct positive (2) & 76 & 44.2 \\
\hline Strong positive (3) & 10 & 5.8 \\
\hline
\end{tabular}

Table 2: Prevalence of sub clinical mastitis at quarter levels $(\mathrm{N}=358)$.

\begin{tabular}{|c|c|c|}
\hline Quarter Infected & Number Positive & Percent \\
\hline RF & 88 & 51.1 \\
\hline LF & 86 & 50.0 \\
\hline RH & 158 & 91.9 \\
\hline LH & 26 & 15.1 \\
\hline
\end{tabular}

\section{Prevalence According to Teat Quarter}

Out of the examined quarters no teat was found to be blind. The quarter level prevalence of sub clinical mastitis from the highest to lowest rate of infection were right front teats (RF) 88 (51.1\%), left hind teat (LH) 26 (15.1\%), left front (LF) 86 (50\%) and hind right teats (HR) 158 (91.9\%) respectively (Table 3).

Table 3: Prevalence in different kebeles $(n=384)$.

\begin{tabular}{|c|c|c|c|}
\hline $\begin{array}{c}\text { Peasant Association } \\
\text { (PA) }\end{array}$ & $\begin{array}{c}\text { Number } \\
\text { Examined }\end{array}$ & $\begin{array}{c}\text { Number } \\
\text { Positive }\end{array}$ & Percent (\%) \\
\hline Bu/Harbu & 68 & 34 & 50 \\
\hline Ba/1ffaa & 13 & 6 & 46 \\
\hline B/Qorodo & 10 & 5 & 50 \\
\hline Damotu & 11 & 7 & 63.6 \\
\hline G/kuyu & 47 & 23 & 48.9 \\
\hline G/Qerans & 26 & 13 & 50 \\
\hline Q/Odo & 11 & 6 & 54.5 \\
\hline Sadamo & 42 & 16 & 38 \\
\hline Shola & 24 & 6 & 25 \\
\hline T/Harbu & 78 & 38 & 71.4 \\
\hline W/Choke & 14 & 10 & 35 \\
\hline Walmara & 40 & 14 & \\
\hline & & & 48.7 \\
\hline
\end{tabular}

\section{Prevalence in different kebeles}

From the twelve kebeles $\mathrm{W} /$ choke (71.4\%) had the highest prevalent sub clinical mastitis case withnumber of animal positive

of 10 from 14. And Sholahave lower sub clinical mastitis case with number of animal positive of $6(25 \%)$ of animals (Table 3 ).

\section{Different Risk Factors}

According to different risk factors categories the highest prevalence was recorded in cross breed, young age group, fourth parity, and first lactation stage (Table 4). There was a statistically significant association $(\mathrm{P}<0.05)$ between the infection of sub clinical mastitis and breed, age group, parity, lactation stage, teat and barn hygiene, mammary gland cleaning and teat deep (Table 5).

Table 4: Prevalence of subclinical mastitis according risk factors.

(1)

\begin{tabular}{|c|c|c|c|}
\hline Breed & $\begin{array}{c}\text { Number } \\
\text { Examined }\end{array}$ & $\begin{array}{c}\text { Number } \\
\text { Positive }\end{array}$ & Percent \\
\hline Local & 223 & 81 & 47.7 \\
\hline Cross & 161 & 91 & 52.9 \\
\hline \multicolumn{4}{|c|}{ Age } \\
\hline Young (4-7) & 321 & 124 & 72.1 \\
\hline Old (>8) & 63 & 48 & 27.9 \\
\hline
\end{tabular}

\section{.}

\begin{tabular}{|c|c|c|c|}
\hline \multicolumn{4}{|c|}{ Parity } \\
\hline First & 6 & 12 & 7 \\
\hline Second & 125 & 34 & 19.8 \\
\hline Third & 74 & 40 & 23.3 \\
\hline Fourth & 95 & 64 & 37.2 \\
\hline Fifth & 25 & 17 & 9.9 \\
\hline Sixth & 6 & 5 & 2.7 \\
\hline
\end{tabular}

\begin{tabular}{|c|c|c|c|}
\hline \multicolumn{3}{|c|}{ Lactation Stage } \\
\hline First & 178 & 7 & 2.7 \\
\hline Second & 93 & 38 & 21.3 \\
\hline Third & 113 & 63 & 36.7 \\
\hline
\end{tabular}

\begin{tabular}{|c|c|c|c|}
\hline Third & 113 & 63 & 36.7 \\
\hline \multicolumn{4}{|c|}{ Teat Hygiene } \\
\hline Good & 82 & 20 & 11.6 \\
\hline Mild & 220 & 93 & 54.1 \\
\hline Poor & 82 & 59 & 34.3 \\
\hline \multicolumn{4}{|c|}{ Barn Hygiene } \\
\hline Good & 80 & 17 & 9.9 \\
\hline Mild & 245 & 110 & 64 \\
\hline Poor & 59 & 45 & 26.2 \\
\hline \multicolumn{4}{|c|}{ Teat Deep } \\
\hline After & 4 & 2 & 1.2 \\
\hline Before & 222 & 79 & 45.9 \\
\hline Non & 158 & 91 & 52.9 \\
\hline \multicolumn{4}{|c|}{ Mammary Gland Cleaning } \\
\hline Before & 311 & 112 & 70.9 \\
\hline After & 1 & 0 & 0 \\
\hline Non & 72 & 50 & 29.1 \\
\hline \multicolumn{4}{|c|}{ Hand Wash During Milking } \\
\hline Washed & 345 & 140 & 81.4 \\
\hline Non & 39 & 32 & 18.6 \\
\hline
\end{tabular}


Table 5: Prevalence of subclinical mastitis against the associated variable.

\begin{tabular}{|c|c|c|c|c|c|}
\hline Breed & No. Examined & No. Positive & Percent & p-value & $x_{2}$ value \\
\hline Local & 223 & 81 & 36.3 & \multirow{2}{*}{15.426} & \multirow{2}{*}{0.000} \\
\hline Cross & 161 & 91 & 56.5 & & \\
\hline \multicolumn{6}{|c|}{ Age } \\
\hline Young (4-7) & 321 & 124 & 40 & \multirow{2}{*}{74.349} & \multirow{2}{*}{0.000} \\
\hline Old $(>8)$ & 63 & 48 & 60 & & \\
\hline \multicolumn{6}{|c|}{ Parity } \\
\hline First & 6 & 12 & 20 & \multirow{6}{*}{62.819} & \multirow{6}{*}{0.000} \\
\hline Second & 125 & 34 & 27.2 & & \\
\hline Third & 74 & 40 & 54.1 & & \\
\hline Fourth & 95 & 64 & 64.7 & & \\
\hline Fifth & 25 & 17 & 70.8 & & \\
\hline Sixth & 6 & 5 & 83.3 & & \\
\hline \multicolumn{6}{|c|}{ Lactation Stage } \\
\hline First & 178 & 7 & 40.1 & \multirow{3}{*}{9.758} & \multirow{3}{*}{0.045} \\
\hline Second & 93 & 38 & 40.9 & & \\
\hline Third & 113 & 63 & 58.9 & & \\
\hline \multicolumn{6}{|c|}{ Teat Hygiene } \\
\hline Good & 82 & 20 & 24.4 & \multirow{3}{*}{41.024} & \multirow{3}{*}{0.000} \\
\hline Mild & 220 & 93 & 42.9 & & \\
\hline Poor & 82 & 59 & 72.0 & & \\
\hline \multicolumn{6}{|c|}{ Barn Hygiene } \\
\hline Good & 80 & 17 & 21.2 & \multirow{3}{*}{41.574} & \multirow{3}{*}{0.000} \\
\hline Mild & 245 & 110 & 44.9 & & \\
\hline Poor & 59 & 45 & 76.3 & & \\
\hline \multicolumn{6}{|c|}{ Teat Deep } \\
\hline After & 4 & 2 & 50 & \multirow{3}{*}{19.683} & \multirow{3}{*}{0.000} \\
\hline Before & 222 & 79 & 36.1 & & \\
\hline Non & 158 & 91 & 57.6 & & \\
\hline \multicolumn{6}{|c|}{ Mammary Gland Cleaning } \\
\hline Before311 & 311 & 112 & 39.2 & \multirow{3}{*}{22.399} & \multirow{3}{*}{0.000} \\
\hline After1 & 1 & 1 & 0 & & \\
\hline Non72 & 72 & 50 & 69.4 & & \\
\hline \multicolumn{6}{|c|}{ Hand Wash During Milking } \\
\hline Washed & 345 & 140 & 40.6 & \multirow{2}{*}{25.370} & \multirow{2}{*}{0.000} \\
\hline Non & 39 & 32 & 82.1 & & \\
\hline
\end{tabular}

\section{Discussion}

In Ethiopia, subclinical mastitis is considered to be an important challenge for the dairy development. This study also indicates subclinical mastitis to be the major problem in the study area. In the present study, the overall prevalence of sub clinical mastitis is $44.8 \%$ at cow level. This finding is almost similar to finding of [13] who reported from 262 cows examined, 105 (40.1\%) and from 1048 quarters examined, 170 (16.1\%) were positive for sub-clinical mastitis using CMT IN in Bishoftu Town and lower in comparison with finding of [14], who reported that the overall mastitis prevalence in the farm was $66.6 \%$ in Assella Dairy Farm in
Oromia Region, Ethiopia which could be due to lack of awareness, housing and milking practices they are accustomed in the area. Subclinical mastitis is a complex disease and the prevalence could be affected due to variation in management system, age, milk yield, body condition, parity, environment and other conditions. Thus, these factors might have contributed to the observed differences in prevalence of subclinical mastitis.

The risk factor considered for this study was breed, age group, parity and lactation stage. In the present study from selected potential risk factors breed, age, stage of lactation, and parity had statistically significant effect $(\mathrm{P}<0.05)$ on the occurrence of mastitis 
which agrees with the report by [15]. Similarly, the environment risk factors considered for this study were teat and barn hygiene, mammary gland cleaning and teat deep. The occurrence of mastitis based on these risk factors showed statistically significant effect with the occurrence of sub clinical mastitis. This was also reported by several investigators to have association with the occurrence of sub clinical mastitis mastitis [16-19]. The study showed that there were significant statistical associations $(p<0.05)$ with the prevalence of mastitis and the parity number of animals; cows with many numbers of calves were with higher prevalence of mastitis and the risk of subclinical mastitis increases with increasing parity number which agrees with the finding of [19-22] who found that the risk of clinical and subclinical mastitis increase significantly with increasing parity number of the cow.

The higher prevalence in cows at three and above calved could be due to increase ease of penetration of the teat duct by pathogens and accumulated previous infection [23]. It is postulated that younger animal is less susceptible; through a more effective host defence mechanism. Older cows, especially after four calving are more prone to mastitis [24]. The present study indicated sub clinical mastitis is a prevalent disease in lactating cows in Wolmera district. Breed, age, parity, and management system are the main factors that were associated with mastitis. The subclinical cases are by far more frequent than the clinical ones. Unequivocally, silent loss of milk production due to subclinical mastitis along with blind teats could cause adverse effect on the dairy activity of the study area that guarantees serious attention in creating awareness and prevention strategy. Ethiopian dairy farmers are not well informed about the invisible loss from subclinical mastitis and thereby there is no practice of subclinical mastitis screening tests. In conclusion, in Ethiopia, the subclinical form of mastitis received little attention and efforts have been concentrated on the treatment of clinical mastitis, however high economic losses often come from subclinical mastitis [24,25].

\section{Authors Contributions}

BG: participated in the design of the study, conducted laboratory work, involved in data analysis and manuscript preparation. DA: participated in the design of the study, involved in data analysis and manuscript preparation. Both authors read and approved the final manuscript.

\section{Acknowledgements}

The authors acknowledge Wollega University for arranging this research.

\section{Availability of Data and Materials}

All relevant data supporting the conclusions of this article are contained within the article.

\section{Ethics Approval and Consent to Participate}

The protocol was approved by the ethical review board of the School of veterinary medicine, Wollega University. Informed written consent was taken from all participants prior to participation in this study.

\section{Funding}

No specific funding for this study was received.

\section{References}

1. (2008) CSA (Central Statistical Authority), Statistical Abstract 2007.CSA, Addis Ababa, Ethiopia.

2. Fekadu K (1995) Survey on the prevalence of bovine mastitis and the predominant causative agents in Chaffa valley. Proceedings of the 9th Conference of Ethiopian Veterinary Association: Addis Ababa, Ethiopia. pp. 101-111.

3. Souto LI, Minagawa CY, Telles EO, Garbuglio MA, Amaku M (2010) Correlation between mastitis occurrence and the count of microorganisms in bulk raw milk of bovine dairy herds in four selective culture media. J Dairy Res 77: 63-70.

4. Donovan DM, Kerr DE, Wall RJ (2005) Engineering disease resistant cattle. Transgenic Res 14: 563-567.

5. Pillai SR, Kunze E, Sordillo LM, Jayarao BM (2001) Application of differential inflammatory cell count as a tool to monitor udder health. J Dairy Sci 84: 1413-1420.

6. Dingwell RT, Leslie KE, Schukken YH, Sargeant JM, Timms LL (2003) Evaluation of the California mastitis test to detect an intramammary infection with a major pathogen in early lactation dairy cows. Can Vet J 44: 413-415.

7. Gharagozloo F, Blourchi M, Tabatabaee AM, Ghasemzadeh Nava H (2003) Sensivity and specifity California mastitis test to detect subclinical mastitis in dairy cows. Pajouhesh and Sazandegi 59: 59-62.

8. Husien NT, Yehualashet G Tilahun (1999) Prevalence of Mastitis in Different Local and ExoticBreed of Milking Cows. Ethiopian Journal of Agricultural Science 16: 53-60.

9. (2010) CSA (Central Statistical Agency), Livestock and Livestock Characteristics, AgriculturalSample Survey. Statistician Bulletin 2(468): 107.

10. Mungube EO (2001) Management and economics of dairy cow mastitis in the urban and periurban areas of Addis Ababa (Addis Ababa milk shed). Faculty of Veterinary Medicine, Addis Ababa University, DebreZeit, MSc Thesis.

11. Radostits OM, Gay CC, Hinchcliff KW, Constable PD (2007) Veterinary Medicine, A Textbook of the Diseases of Cattle, Sheep, Pigs, Goats and Horses.(10 Edn.), Saunders Elsevier, Spain pp. 1045-1046.

12. Thrusfield M (2005) Veterinary Epidemiology, $\left(2^{\text {nd }}\right.$ Edn.), UK: Black Well Science. p. 180.

13. Birhanu M, Leta S, Mamo G (2017) Prevalence of bovine subclinical mastitis and isolation of its major causes in Bishoftu Town, Ethiopia. BMC Res Notes 10: 767.

14. Birhanu A, Diriba L, Iyob I (2013) Study of bovine mastitis in Asella government dairy farm of Oromia Regional state. South Eastern Ethiopia 1(2): 134-145.

15. Zeryehun T, Aya T, Bayecha R (2013) Study on prevalence, bacterial pathogens and associated risk factors of bovine mastitis in smallholder dairy farms in and around Addis Ababa, Ethiopia. The J of Ani\& Plant Scie 23(1): 50-55. 
16. Biffa D, Debela E, Beyene F (2005) Prevalence and Risk Factors of Mastitis in Lactating Dairy Cows in Southern Ethiopia. Intern J Appl Res Vet Med 3(3): 189-192.

17. Mekibib B, M Furgasa, F Abunna, B Megersa, A Regassa (2010) Bovine Mastitis: Prevalence, Risk Factors and Major Pathogens in Dairy Farms of Holeta Town, Central Ethiopia. Vet World 3(9): 397-403.

18. Benta D, Abtamu T (2011) study on Prevalence of Mastitis and its Associated Risk Factors in Lactating Dairy Cows in Batu and its Environs, Ethiopia. Global veterinaria 7(6): 632-637.

19. Nibret M, Hailemariam T, Fentahun T, Chanie M, Melaku A (2012) Bovine Mastitis and Associated Risk Factors in Small Holder Lactating Dairy Farms in Hawassa, Southern Ethiopia. Global Veterinaria 9(4): 441-446.

20. Busato A, Trachsel P, Schalibaum M, Blum JW (2000) Udder health and Risk factor for sub clinical mastitis in organic dairy farm in Switzerland. Prev Vet Med 44: 205-220.

ISSN: 2574-1241

DOI: 10.26717/BJSTR.2020.28.004621

Debela Abdeta. Biomed J Sci \& Tech Res

(C) This work is licensed under Creative

Submission Link: https://biomedres.us/submit-manuscript.php
21. Bitew M, Tafere A, Tolossa T (2010) Study on bovine mastitis in dairy farms of Bahir Dar and its environments. J Vet AnimAdv 9: 2912-2917.

22. Girma D (2010) Study on prevalence of dairy cows around Holeta Areas, West Shewa Zone of Oromia Region, Ethiopia. Global Veternaria 5: 318323.

23. Radostits OM, Gay CC, Hinch, KW (2002) Mastitis Veterinary Medicine. A text book of disease of cattle, sheep, pigs, goats and horses ( $9^{\text {th }} \mathrm{Edn}$.), WB Saunders, London, UK. pp. 603-700.

24. Dullin AM, Paape MJ, Nickerson SC (1988) Comparison of phagocytosis and chemiluminescence's by blood and mammary gland neutrophils from multi parous cows. Am J Vet Res 49: 172-177.

25. Hussein N, Yehualashet T, Tilahun G (1997) Prevalence of mastitis in different local and exotic breeds of milking cows. Eth J Agr Sci 16: 53-60.

\begin{tabular}{ll} 
BIOMEDICAL & Assets of Publishing with us \\
RESEARCHES & - Global archiving of articles \\
& - Immediate, unrestricted online access \\
\hline ISSN: $2574-1241$ & - Rigorous Peer Review Process \\
&
\end{tabular}

